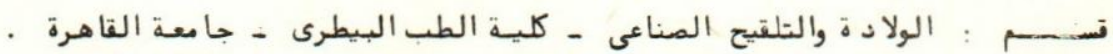

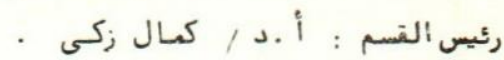

$$
\begin{aligned}
& \text { مهـا ولات زياد مة معد لات الاخصاب فى حس حسلــالات } \\
& \text { التفويت بالجاموس والأبقار }
\end{aligned}
$$

محمد الحريرى ، محف عمر ، كال زكى

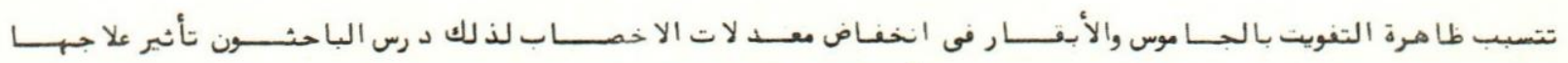

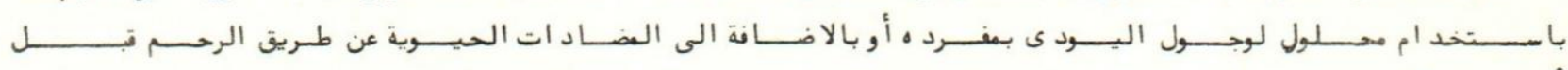


Dept. of Gynaecology, Obstetrics and A.I.

Faculty of Vet. Med., Cairo university,

Head of Dept. Prof. Dr. K. Zaki.

\title{
TRIALS FOR INCREASING CONCEPTION RATE IN REPEAT BREEDING BUPPALOES AND CATTLE (With 3 Tables)
}

By

\author{
M.N.E. ELHARIRI, M.A. OMAR and K. ZAKI
}

(Received at $6 / 12 / 1977$ )

SUMMARY

\begin{abstract}
Repeat breeding in buffaloes and cattle reduce their reproductive efficiency. Therefore, evaluation of the effect of intrauterine infusion with Lugol's iodine and/or antibiotics before or after insemination for increasing their conception rates were tried and factors affecting the results were discussed.
\end{abstract}

\section{INTRODUCTION}

Repeat breeding in buffaloes and cattle is a great economic problem for the reduction of reproductive efficency due to failure of fertilization ( REARUEN, 1954 and ROBERTS, 1971 ) or early embryonic mortality (TANABE and ALMQUIST, 1953 and BHOSREKAR, 1973). Many causes are increminated such as bacterial ( MENGE, WINTER, MC NUTT and CASIDA, 1961); viral ( TANABE and ALMQUIST, 1953 ); nutritional ( WI TBANK and FAULKNER, 1970); hormonal (DAWSON, 1953); congenital (GUSTAFSSON, 1971) and/or unknown factors (ROBERTS. 1971 ).

Good results for treatment of this abnormality were obtained in cattle using intrauterine infusion with Lugol's iodine solution alone (MACKAY and THOMSON, 1958 and ZAKI, SABBER, FOUAD and ELWISHY,1963) or penicillin and streptomycin (MILLS, 1958 and LUKTUKE and JOSHI, 1961).

The present investigation was planned to evaluate the effect of intrauterine infusion with Lugol's iodine and/ or antibiotics before or after insemination on the conception rate of repeat breeding buffaloes and cattle.

\section{EXPERIMENTAL}

A total number of 387 animals, 247 buffaloes and 140 cows, brought to Aussium A.I. Centre were used for this study. Case history, clinical examination, rectal and vaginal inspections and biometrics of the genital organs of each individual were carefully noticed and registered.

The animals were divided into seven experimental and control groups in the following manner:

Experiment I:

Each of eighty-two repeat breeding buffalo-cows was given $50 \mathrm{ml}$. of Lugol's iodine solution 0.58 ( 1 gm. iodine, and $196 \mathrm{ml}$. distilled water) for two times of intrauterine infusion at 14- and 7-days before insemination.

Experiment II:

Each of fourty three repeat breeding buffalo-cows was given the previous treatment as experiment I followed by antibiotics (1.800.000 I.U. procaine penicillin G and 2 gm. dihyrostreptomycin "Cid-Cairo" dissolved in 50 ml. dist. water) intrauterinally at 24 hours after insemination.

Experiment III:

Each of eight repeat breeding buffalo-cows was given an intrauterine infusion of Lugol's iodine solution at 24 hours after insemination.

Experiment IV:

Each of $\mathrm{fifty-four}$ repeat breeding buffalo-cows was given an intratuterine antibiotics infusion at 24 hours after insemination.

Experiment V:

The control group of sixty repeat breeding buffalo-cows were inseminated without any treatment. 


\section{M.N.E. ELHARIRI, et al.}

Experiment VI:

Seventy-eight repeat breeding cows were treated similarily as experiment $I$.

\section{Experiment VII:}

Sixty-two repeat breeding cows were treated similarily as experiment II.

After treatment, the buffaloes were artificially inseminated in the proper time using semen of fertile-bulls diluted with egg-yolk-glucose-bicarbonate dilutent (four parts of glucose solution 58 , one part of sodium bicarbonate 1.38 and one part of fresh hen egg yol and the cows were inseminated with fertile Freiseian bulls semen diluted with egg yolk citrate dilutent (four parts of sodium citrate dihydrate 2.98 and one part of fresh hen egg yolk). For each one $\mathrm{ml}$. of the dilutent $500 \mathrm{I} . \mathrm{U}$. penicillin and $0.5 \mathrm{mg}$. streptomycin were added.

RESULTS

The obtained data indicate that the conception rate of repeat breeding buffaloes and cattle locally treated by intrauterine infusion with Lugol's iodine solution and/or antibiotics have an inverse relationship to the number of previous non fertile services as clear in Table $1 \& 2$.

Combined intrauterine treatment of Lugol's iodine solution two times at a week interval before the insemination which followed by antibiotics 24 hours later have better results for increasing the conception rates in repeat breeders (48.848 in buffaloes and 56.548 in cattle) than using I gol's iodine solution alone either insemination ( 42.688 in buffaloes and 38.468 in cattle respectively) or after insemination ( 25.008 in buffaloes) or using antibiotics after insemination in buffaloes $(40,748)$.

It is of interest to notice that rectal and vaginal inspections revealed a lower incidence of clinical abnormal genital tracts in buffalo-cows (28.758) than cattle (39.268) with higher percentage of cases of endornetritis (16.548) and cervicitis (7.758), as shown in Table 3, that can respond for trials of treatment with good. results.

\section{DISCUSSION}

Local intrauterine therepy with weak iodine solution seems to be good for its microbiocidal action and the slight uterine irritation that leads to hyperaemia and leucocytosis as well as for its rappid absorption to activate the thyroid gland (ECKMAN, HOLMERG, SETTERGERN and THORELL, 1965) resulting in higher conception rate of repeat breeding buffaloes and cattle that treated two times with a week interval before insemination. Similar results in cattle were noticed by $2 A K I$ et al., (1963) and ROBERTS (1971) but SWENSSON (1971) did not find the significant effect of Lugol's iodine solution.

Furthermore, intrauterine infusion with antibiotics at 24 hours after insemination is an effective treatment for increasing the conception rate in repeat breeding buffaloes for the bacteriocidal effect of penicillin on gram positive bacteria and streptomycin on gram negative ones. Similar results were obtained in cattle by SMITH (1957); LUKTUKE and JOSHI (1961) and DE COSTA GUERRIERO (1966) but other investigators failed to find a significiant improvement in fertility rate after the same treatment that may be attributed to the condition of the genital organs of their experimental and control animals and the subclinical affections which could result in a misleading conclusions (DE BOIS, 1961; GIBBONS and KIESEL, 1963 and ROBERTS, 1971).

On the other hand, it was proved that the most effective treatment in the mentioned four trials, irrespective to the species of animal treated or the number of the previous non-fortile services, was obtained after the intrauterine infusion with combined Lugol's iodine and antibiotics solutions that increase the conception rate in repeat breeders to the highest level (48.848 in buffalo-cows and 56.458 in cattle).

Moreover, the present results indicate that the fertility rate was increased when the repeat breeders treated as soon as possible for prevention of the chronic stage and minimize the possiblility of complications that was in agreement with the observations of HINZE (1959) and LUKTUKE and JOSHI (1961).

Also, the natural microbial resistance of buffaloes was indicated by their lower incidence (28.758) of clinical abnormal genital tracts than cattle (39.298) although better respond for the treatment in the later species 


\section{REPEAT BREEDING IN BUFFALOES AND CATTLE}

(58.18\% conception rate) than the former (30.80\%) draws the attention of the great role of the genitic influence and endocrine disorders in the problem of repeat breeding in buffaloes that need further investigations.

In animals diagnosed clinically to suffer from different pathological changes in genital tracts, there are two major groups, those with cervical affections (7.75\%) and the other which have had enodmetritis (16.54\%). Although good results for treatment of endometritis cases (41.67\% in buffaloes and 57.14 in cattle) with intrauterine infusion of Lugol's iodine solution only for two times with a week interval before insemination that was in accordance to the findings of ZAKI et al., (1963), but the present investigation indicate that this treatment in combination with the antibiotics mixture 24 ho rs after insemimination is the most efficient treatment in cases of endometritis as the conception rates were increased to $62.50 \%$ in buffaloes and 73.338 in cattle.

\section{REFERENCES}

Bearden,H.J. (1954): Fertilization and embryonic mortality rates for bulls with histories of low or high fertility in artficial breeding. Thesis, Cornell Univ., Ithaca, N.Y.

Bhosrekar,M. (1973): Investigations into the incidence and causes of repeat breeding in dairy cattle at National Dairy Research Institute, Karnal (Haryana). Ind. Vet. J., 50: 418.

Da Costa Guerreiro,R.T. (1966): Improved fertility in dairy cow by intrauterine infusion of antibiotics after artificial insemination. An Escola Med. Vet., Lisboa 2: 59.

Dawson,F.L.M. (1953): Progesterone in functional infertility of cattl. Vet. Rec., 66: 324.

De Boiss, C.H.W. (1961): Endometritis En Verohtobaaheid Bij Het Rund. Thesis, Utrecht.

Eckman,L., Holmerg, O., Settergern, I. and Thorell, C.B. (1965): Resor ion of iodine in Lugol's solution and in iodophor from the uterus of buffalo-cows. Nord,Vet. Med., 17: 391.

Gibbons,W.J. and Kiesel,G.K. (1963): Antibiotic uterine infusion to aid fertility. Cornell Vet. 54 : 382.

Gustafsson, I. (1971): Chromosomes of repeat-breeders heifers. Herediats, $63: 68$.

Hinze,P.M. (1959): Diagnosis and treatment in dairy cow. J. Amer. Vet. Med. Assoc.., 134 : 302.

Luktuke,S.N. and Joshi,S.R. (1961): Intrauterine treatment of repeat breeders with antibiotics. Ind. J.Vet. Sei., 31: 10 .

Mac Kay,G.W. and Thomsom,J.D. (1958): Field observation on the use of two treatments for repeat breeder cows. Canda. J. Comp. Med. 22: 21.

Menge, A.C., Winter, A.J., MC Nutt, S.H. and Casid, L.E. (1961): The effect of repeated intrauterine inoculations with bacteria on subsequent fertility in heifers. J. Dairy Sci., 44: 1186.

Mills, A.M. (1958): Infertility in cattle. Vet. Med., 53: 507.

Soberts, S.J. (1971) : Veterinary obstetrics and genital diseases. Edwards Brothers, Inc. Ann. Arbor., Michigan.

Smith, L.C. (1957): Tratment of beef cows to eliminate repeat breeding. Norh. Am. 38 : 36 .

Swensson, T. (1971): Experiments with Lugol's solution portio treatment following A.I. in cattle. Medan. Svensk. Huadjurs Skotsel, 49: 52 .

Tanabe, T.Y. and Almquist, J.O. (1953): Some causes of infertility in dairy heifers. J. Dairy Sci., 32: 237.

Wiltbank, J.N. and Faulkner, L.C. (1970): The mangagement of beef breeding programs. Bov. Pact. 5: 23.

Zaki,K., Saber,M.S., Gouad,M.S. and El-Wishy,A.B. (1963): Treatment of chronic catarrahal endometritis in Friesian cows by Lugol's iodine. 4 th Arab Ann. Vet. Congr. : 349. 


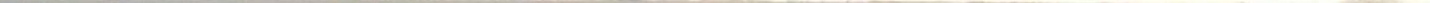


REPEAT BREEDING IN BLIFFALOES AND CATTLE

\section{TABLe (2)}

Conception rate in repeat breeding cows in relation to frequency of provious unsucessful services before uterine therapy.

\begin{tabular}{|c|c|c|c|c|c|c|c|}
\hline \multirow{2}{*}{\multicolumn{2}{|c|}{$\begin{array}{l}\text { Times bred } \\
\text { before } \\
\text { treatment }\end{array}$}} & \multicolumn{3}{|c|}{$\begin{array}{l}\text { Lugol's before insemination } \\
\text { (Experiment VI) }\end{array}$} & \multicolumn{3}{|c|}{$\begin{array}{l}\text { Lugol's before insemina- } \\
\text { tion \& antibiotics af- } \\
\text { ter insem. } \\
\quad \text { (Experiment VII) }\end{array}$} \\
\hline & & $\begin{array}{l}\text { No. of } \\
\text { treated } \\
\text { cows }\end{array}$ & $\begin{array}{l}\text { No. of } \\
\text { pregnant } \\
\text { cases }\end{array}$ & $\begin{array}{l}\text { C. R. } \% \\
\text { after } \\
\text { treatment }\end{array}$ & $\begin{array}{l}\text { No. of } \\
\text { treated } \\
\text { cows }\end{array}$ & $\begin{array}{l}\text { No. of } \\
\text { pregnant } \\
\text { cases }\end{array}$ & $\begin{array}{l}\text { C. R. } \% \\
\text { after } \\
\text { treatment }\end{array}$ \\
\hline 2 & -4 & 50 & 22 & 44.00 & 43 & 30 & 69.77 \\
\hline 5 & -6 & 16 & 6 & 37.00 & 12 & 4 & 33.33 \\
\hline 7 & -8 & 8 & 2 & 25.00 & 5 & 1 & 20.00 \\
\hline 9 & -10 & 4 & 0 & 00.00 & 2 & 0 & 00.00 \\
\hline \multicolumn{2}{|c|}{ Total } & 78 & 30 & 38.40 & 62 & 35 & 56.45 \\
\hline
\end{tabular}

Assiut Vet.Med.J.Vol. 8, No. 15816,1981. 


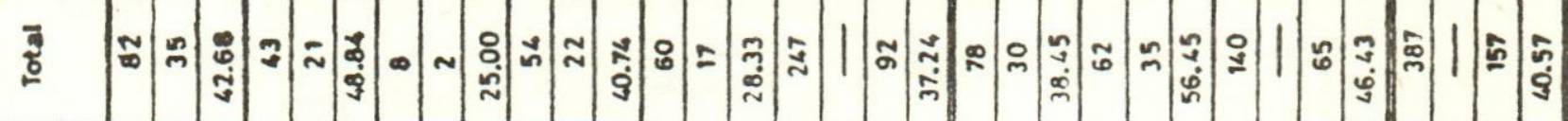

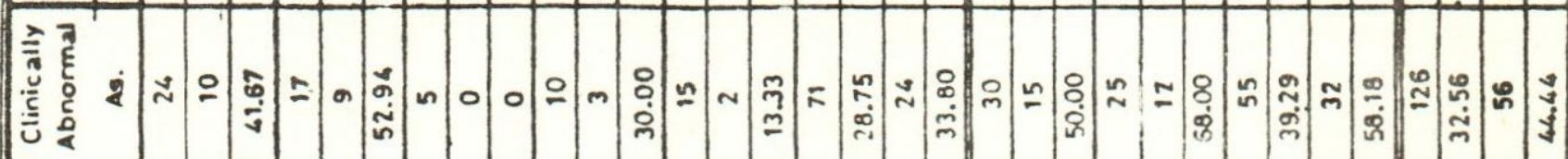

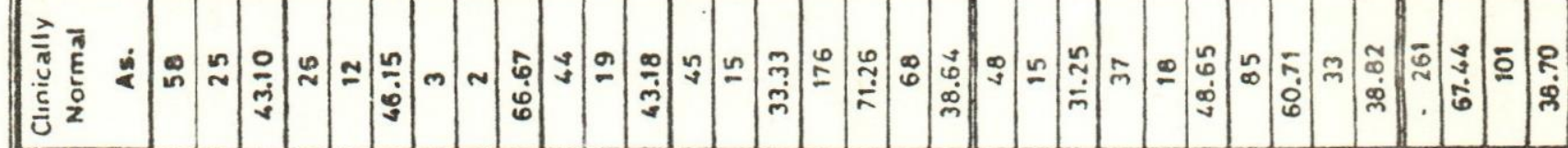

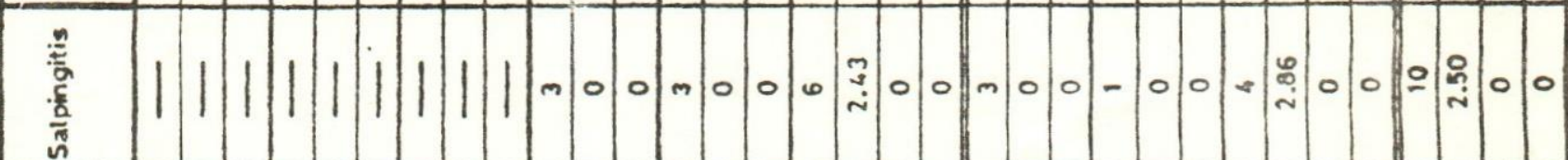

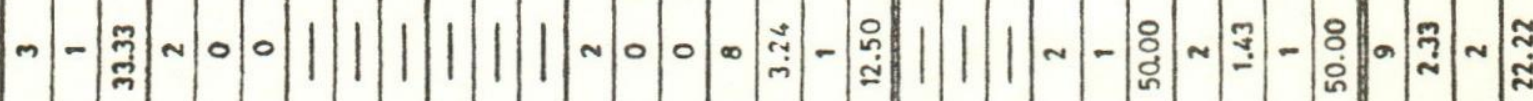

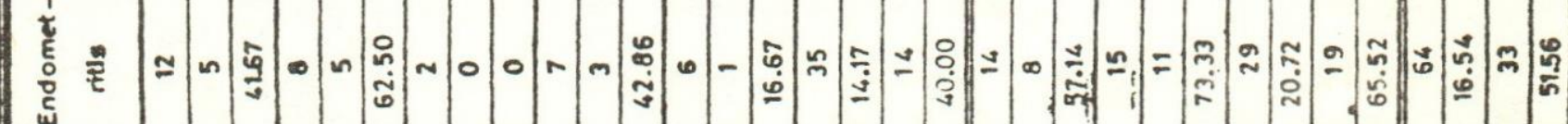

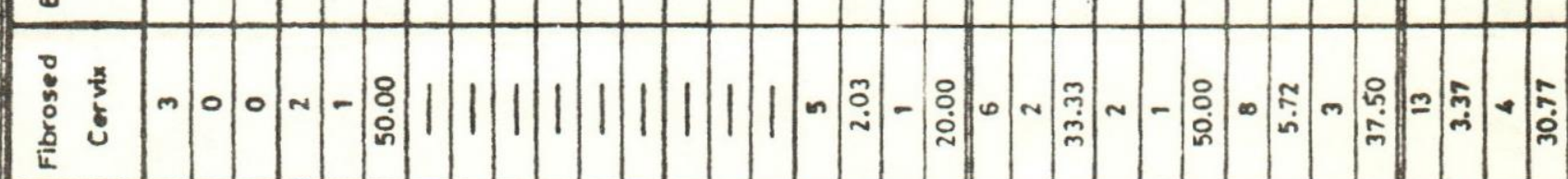

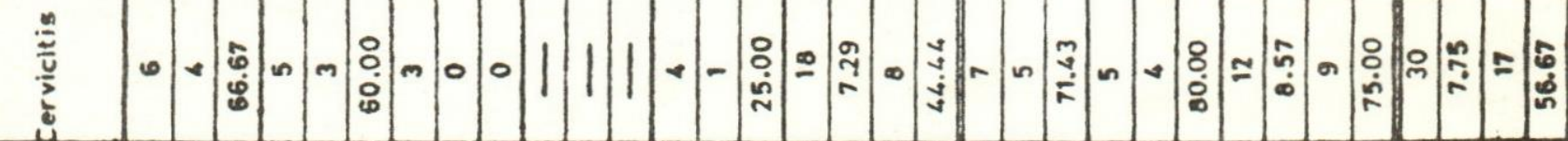

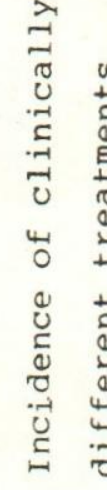

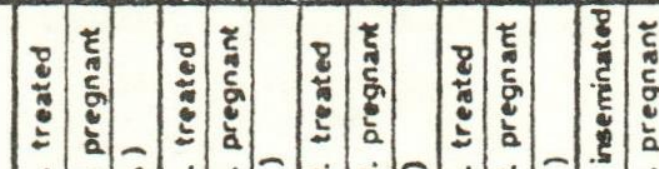
خे 万人

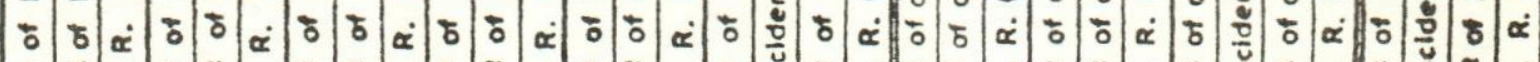
安

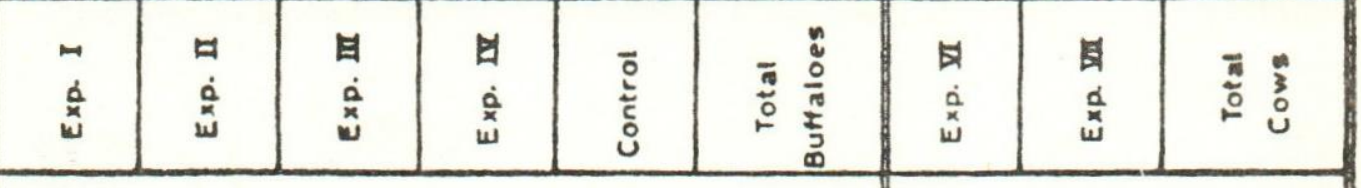

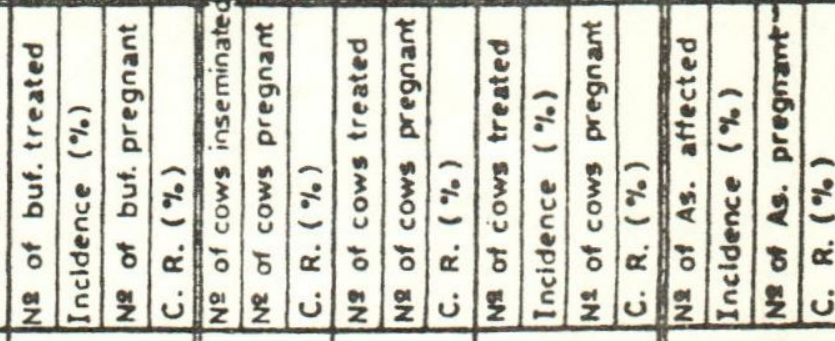


